\title{
DEIERMINATION OF COLLECTIVE EFFECTIVE AND EQUIVALENT DOSES AND RADIATION RISK OF THE UKRAINIAN POPULATION FROM X-RAY DIAGNOSTIC EXAMINATIONS
}

\author{
Stadnyk L.L., Nosyk O.V. \\ ВИЗНАЧЕННЯ КОЛЕКТИВНИХ ЕФЕКТИВНИХ ТА ЕКВІВАЛЕНТНИХ ДОЗ \\ І РАДІАЦІЙНИХ РИЗИКІВ НАСЕЛЕННЯ УКРАЇНИ ЗА РАХУНОК \\ РЕНТГЕНОДІАГНОСТИЧНИХ ДОСЛПДЖЕНЬ
}

\author{
СТАДНИк Л.Л., \\ НОСИК О.В. \\ ДУ «Інститут медичної \\ радіології ім. С.П. Григор'єва \\ Національної академії \\ медичних наук України», \\ м. Харків \\ Istadnyk@ukr.net \\ Ключові слова: \\ рентгенодіагностичні \\ дослідження, \\ колективні ефективні \\ та еквівалентні дози, \\ радіаційні ризики.
}

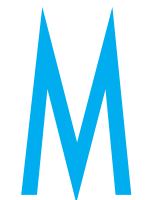

едичне опромінення $€$ основним чинником радіаційного впливу надфонового опромінення населення. Додаткове радіаційне опромінення підвищує ризик виникнення в опромінених осіб радіаційних стохастичних ефектів у вигляді додаткових випадків злоякісних пухлин та генетичних ефектів. Обґрунтування та виправданість призначення рентгенодіагностич- них досліджень базуються на зіставленні очікуваної користі процедури з оцінкою радіаційних ризиків індукування додаткових випадків онкологічних захворювань [1].

Мірою визначення радіаційного ризику є ефективна доза, яка використовується для оцінки дози опромінення усього тіла людини з урахуванням різної радіочутливості окремих органів та тканин. Однак у концепцію ефективної дози по-
ОПРЕДЕЛЕНИЕ КОЛЛЕКТИВНЫХ ЭФФЕКТИВНЫХ И ЭКВИВАЛЕНТНЫХ ДОЗ И РАДИАЦИОННОГО РИСКА НАСЕЛЕНИЯ УКРАИНЫ ЗА СЧЕТ РЕНТГЕНОДИАГНОСТИЧЕСКИХ ИССЛЕДОВАНИЙ Стадник Л.Л., Носик О.В.

ГУ «Институт медицинской радиологии им. С.П. Григорьева Национальной академии медицинских наук Украины», г. Харьков

Цель работы - определение коллективных эффективных и эквивалентных доз облучения населения Украины и оценка радиационных рисков по выбранным видам рентгенодиагностических исследований.

Методы исследований. Проведены расчеты коллективных эквивалентных и эффективных доз населения от наиболее массовых видов рентгенодиагностических исследований на основании данных национального анкетирования структуры исследований, парка рентгеновского оборудования в Украине. Данные об эквивалентных и эффективных дозах «стандартного» пациента при рентгенографических исследованиях были получены по результатам фантомного моделирования условий облучения пациентов и ранее проведенных исследований входных поверхностных доз пациентов. Оценен абсолютный и относительный радиационный риск возникновения дополнительных случаев онкологических заболеваний у населения Украины от рентгенодиагностических исследований. Результаты и их обсуждение. Установлено, что при рентгенодиагностических исследованиях на рентгеновских аппаратах старых моделей (аналоговые системы) эффективные дозы «стандартных» пациентов выше в 1, 1-5,5 раза, чем на современных аппаратах с цифровыми приемниками изображений. Это связано с использованием на аналоговых аппаратах более высоких значений экспозиции. По результатам оценки коллективных доз установлено, что в последние годы отмечается тенденция к их снижению, что связано с уменьшением численности населения страны и частичной заменой аналоговых аппаратов на цифровые системы визуализации. Основной вклад в суммарную коллективную эффективную дозу населения Украины от рентгенодиагностических исследований дает пленочная флюорография от 53,9\% в 2011 г. до 40,0\% - в 2017 г., тогда как вклад цифровой флюорографии составляет 2,86,7\% за годы наблюдения. Абсолютный ожидаемый риск за счет проведения наиболее массовых и дозоформирующих видов рентгенодиагностических исследований в проекционной рентгенологии составляет 1485, 6 случаев в год, при этом основной вклад формирует пленочная флюорография - 697,3 случаев (47\%), тогда как цифровая флюорография составляет 117 случаев.

Выводы. Коллективная эффективная доза населения Украины за счет наиболее массовых исследований в проекционной рентгенодиагностике в 2017 г. составила 22, 9 тыс. чел. -Зв, тогда как в 2011 г. - 37,5 тыс. чел. -Зв. Абсолютный риск возникновения дополнительных случаев онкозаболеваний за счет выбранных видов рентгенодиагностических исследований составляет 1485, 6 случаев в год, при этом вклад пленочной флюорографии составляет 47\%. Вклад рентгеновских исследований в возрастание фоновой онкологической заболеваемости (атрибутивный риск) составил 1,47\%. Наибольший вклад вносит пленочная флюорография - 0,95\% ввиду проведения массового скрининга заболеваний легких В связи с тем, что атрибутивный риск пленочной флюорографии превышает величину приемлемого риска, необходимо принятие срочных мер по выведению пленочной флюорографии из рентгенологической практики.

Ключевые слова: рентгеновские исследования, коллективные эффективные и эквивалентные дозы, радиационные риски.

(С Стадник Л.Л., Носик О.В. СТАТТЯ, 2019. 
кладено модель рівномірного опромінення усього тіла та дані про коефіцієнти радіаційних ризиків за результатами дослідження радіаційних ефектів у когорти опромінених осіб Хіросіми та Нагасакі. Дана концепція лінійної безпорогової залежності «доза-ефект» була запропонована МКРЗ з метою радіаційного захисту персоналу, що працює з джерелами іонізувального випромінення, та населення. Між тим, модель рівномірного опромінення не відповідає геометрії опромінення людини у рентгенодіагностиці, де у поле прямого струменя потрапляють 3-5 критичних органів, тоді як інші органи отримують дозу на рівні нуля. Отже, використання концепції ефективної дози у рентгенодіагностиці буде зменшувати радіаційний ризик виникнення онкологічних захворювань в окремих органах та тканинах. Тому Міжнародна комісія 3 радіологічного захисту (МКРЗ) у Публікації № 103 переглянула концепцію оцінки ризиків виникнення стохастичних радіаційних ефектів та рекомендувала проводити такі оцінки на основі даних про еквівалентні дози окремих тканин і органів з використанням відповідних коефіцієнтів ризику та з урахуванням вікових і гендерних розподілів осіб [2].

У представленій роботі було прийнято такий підхід при оцінці радіаційних ризиків населення України для найбільш поширених видів рентгенодіагностичних досліджень за результатами розрахунків колективних ефективних та еквівалентних доз опромінення.

Метою роботи було визначення колективних ефективних та еквівалентних доз опромінення населення України й оцінка радіаційних ризиків за обраними видами рентгенодіагностичних досліджень.

Матеріали та методи досліджень. Розрахунок еквівалентних органних та ефективних доз пацієнтів під час найбільш масових рентгенографічних досліджень та флюорографії проведено за встановленими коефіцієнтами переходу та середніми значеннями вхідних поверхневих доз

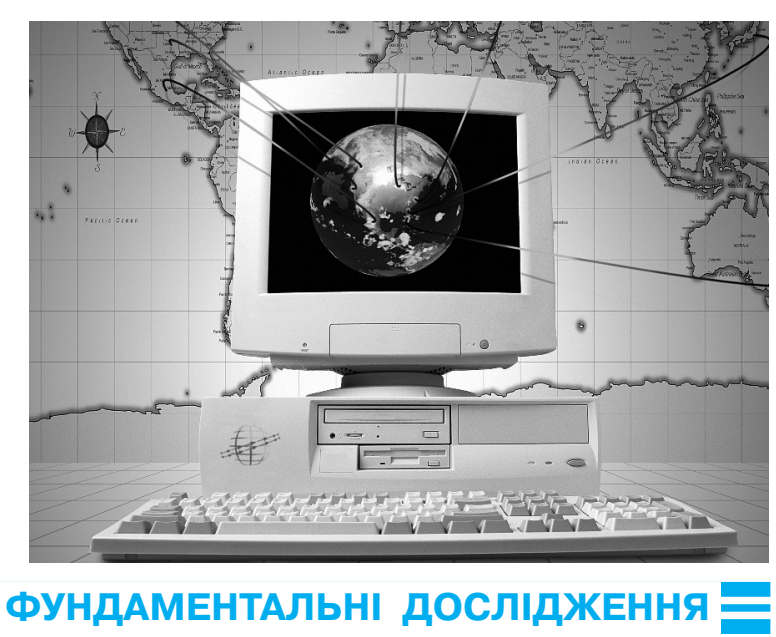

(ВПД) «стандартних» пацієнтів, що отримано за попередніми науковими дослідженнями Інституту медичної радіології [3] за формулою 1:

$$
\mathrm{E}=\text { ВПД · } \mathrm{k},(1)
$$

де ВПД - вхідна поверхнева доза, мГр; k - коефіцієнт переходу від вхідної поверхневої дози до еквівалентних/ефективних доз, мЗв/мГр.

Для визначення коефіцієнтів переходу від ВПД до еквівалентних та ефективних доз проведено фантомні моделювання умов опромінення «стандартної» людини для рентгенографії органів грудної клітки (ОГК), черепа/придаткових пазух носу (ППН), шийного, грудного та поперекового відділів хребта (ШВХ, ГВХ, ПВХ відповідно), кісток тазу та флюорографії. За результатами зіставлення ВПД зі значеннями еквівалентних та ефективних доз, виміряних на фантомі, було визначено відповідні коефіцієнти переходу.

Значення ВПД «стандартних» пацієнтів під час найпоширеніших видів рентгенодіагностичних досліджень було розраховано шляхом прямих вимірювань доз на пацієнтах методом термолюмінесцентної дозиметрії та за результатами анкетування щодо режимів проведення досліджень у різних рентгенодіагностичних кабінетах України і даними радіаційного виходу рентге- нівських апаратів за протоколами контролю дозоформувальних параметрів [3].

Для флюороскопічних досліджень розрахунок ефективних доз за результатами фантомного моделювання (фізичного або математичного) неможливий у зв'язку з тим, що дані дослідження $€$ динамічними. Тому оцінку ефективних доз пацієнтів для флюороскопічних досліджень проводили за результатами вимірювань добутку «доза-площа» (ДДП) та значеннями конверсійних коефіцієнтів згідно з Керівництвом ЄС № 154 щодо оцінки доз населення за видами досліджень [4].

Для мамографічних досліджень оцінку ефективних доз пацієнтів проведено за результатами даних анкетування щодо режимів проведення досліджень та протоколів контролю якості апаратів.

Ефективна доза для мамографії розраховувалась як сума добутків середніх поглинутих доз AGD на кожну молочну залозу у двох проекціях за формулою 2:

$$
E=\sum A G D \cdot w_{T},
$$

де AGD - середня поглинута доза у молочній залозі за один знімок, мГр; $\mathrm{w}_{\top}$ - тканинний зважувальний фактор для молочної залози.

Оцінку колективних еквівалентних та ефективних доз

Таблиця 1

Узагальнені конверсійні коефіцієнти від значень добутку «доза-площа» до ефективної дози

\begin{tabular}{|l|c|}
\hline \multicolumn{1}{|c|}{ Вид дослідження (локалізація) } & $\mathrm{E}_{\text {еф }} /$ ДДП, мЗв/(Гр $\left.\mathrm{cm}^{2}\right)$ \\
\hline Флюороскопія ОГК & 0,10 \\
\hline Флюороскопія шлунка & 0,20 \\
\hline Іригоскопія & 0,28 \\
\hline
\end{tabular}


населення України було проведено для обраних найбільш поширених видів рентгенодіагностичних досліджень на підставі даних анкетування обласних рентгенорадіологічних служб щодо структури, частоти проведення рентгенівських досліджень та парку наявного обладнання. Загальну інформацію про кількість проведених рентгенодіагностичних досліджень отримано 3 довідників Центру медичної статистики МОЗ

України щодо показників діяльності радіологічної служби України за 2011, 2014 та 2017 роки.

Колективна доза $\mathrm{S}_{\mathrm{i}}$ за кожним видом дослідження розраховувалася за формулою 3 [5]

$$
\mathrm{S}_{\mathrm{i}}=\sum \mathrm{E}_{\mathrm{ij}} \cdot \mathrm{N}_{\mathrm{ij}},(3)
$$

де $\mathrm{E}_{\mathrm{ij}}$ - середня ефективна доза від i-го виду рентгенівського дослідження на рентгенівських апаратах $j$-моделі; $\mathrm{N}_{\mathrm{ij}}$ - кількість рентгенівських до-

Таблиця 2

\section{Коефіціенти ризиків опромінення критичних органів} для чоловіків та жінок

\begin{tabular}{|l|c|c|}
\hline \multirow{2}{*}{ Критичний орган або тканина } & \multicolumn{2}{|c|}{ Коефіцієнт ризику, $10^{-4}$ Зв$^{-1}$} \\
\cline { 2 - 3 } & Чоловіки & Жінки \\
\hline Щитоподібна залоза & 1,6 & 7,0 \\
\hline Молочна залоза & 0,0 & 76,6 \\
\hline Стравохід & 12,8 & 14,4 \\
\hline Легені & 80,0 & 165,4 \\
\hline Печінка & 28,5 & 14,7 \\
\hline Товстий кишечник & 62,0 & 27,7 \\
\hline Шлунок & 44,5 & 60,7 \\
\hline Сечовий міхур & 18,6 & 17,7 \\
\hline Гонади & 15,3 & 15,3 \\
\hline Шкіра & 2,7 & 2,7 \\
\hline Червоний кістковий мозок (ЧКМ) & 25,2 & 22,9 \\
\hline Поверхня кістки & 3,4 & 3,4 \\
\hline Інші органи & 70,1 & 80,8 \\
\hline Загалом & 364,7 & 509,3 \\
\hline
\end{tabular}

\section{Середні ефективні дози, загальна кількість рентгенодіагностичних досліджень та колективна ефективна доза населення Україні від найбільш масових видів} рентгенодіагностичних досліджень

\begin{tabular}{|c|c|c|c|c|c|c|c|c|}
\hline \multirow[t]{2}{*}{ Рентгенодіагностичні дослідження } & \multicolumn{2}{|c|}{$\begin{array}{c}\text { E, мЗв на апа- } \\
\text { ратах двох груп }\end{array}$} & \multicolumn{3}{|c|}{$\begin{array}{l}\text { Кількість рентгенодіаг- } \\
\text { ностичних досліджень } \\
\text { на рік, тис. досл. }\end{array}$} & \multicolumn{3}{|c|}{$\begin{array}{c}\text { Колективна ефективна } \\
\text { доза, люд-Зв }\end{array}$} \\
\hline & 1 група & 2 група & 2011 & 2014 & 2017 & 2011 & 2014 & 2017 \\
\hline Плівкова флюорографія & 1,10 & - & 17857,0 & 11199,2 & 8330,5 & 19643,0 & 12319,2 & 9163,6 \\
\hline $\begin{array}{l}\text { Цифрова скринінгова флюорографія } \\
\text { легенів }\end{array}$ & - & 0,20 & 5036,0 & 7466,2 & 7689,7 & 1007,0 & 1493,2 & 1537,9 \\
\hline Рентгенографія органів грудної клітки & 0,08 & 0,06 & 6517,0 & 63 & 6287,7 & 0 & 499,9 & 490,5 \\
\hline Рентгенографія ППН та черепа & 0,09 & 0,06 & 1886,0 & 1838,0 & 1917,8 & 157,8 & 153,8 & 159,1 \\
\hline Рентгенографія шийного відділу хребта & 0,39 & 0,27 & 1188,0 & 897,9 & 936,9 & 435,8 & 329,4 & 341,3 \\
\hline Рентгенографія грудного відділу хребта & 2,54 & 1,95 & 905,0 & 740,5 & 773,0 & 2192,0 & 1794,3 & 1863,1 \\
\hline $\begin{array}{l}\text { Рентгенографія поперекового відділу } \\
\text { хребта }\end{array}$ & 2,59 & 1,22 & 2269,0 & 1742,8 & 1818,5 & 5246,0 & 4029,5 & 4154,6 \\
\hline $\begin{array}{l}\text { Рентгенографія таза та тазостегново- } \\
\text { го суглоба }\end{array}$ & 2,21 & 0,63 & 1080,0 & 1056,6 & 1102,4 & 2038,8 & 1994,6 & 2046,4 \\
\hline Мамографія & 0,66 & 0,36 & 591,0 & 659,8 & 718,3 & 267,3 & 269,1 & 324,9 \\
\hline Флюороскопія легень & 0,47 & 0,38 & 516,0 & 325,6 & 307,6 & 231,4 & 145,9 & 137,9 \\
\hline Флюороскопія шлунка* & $30,3 / 6,8$ & 2,4 & 335,7 & 213,3 & 179,8 & 3565,6 & 2265,2 & 1908,9 \\
\hline Іригоскопія* & $20,4 / 8,9$ & 4,6 & 108,0 & 89,0 & 75,1 & 1120,2 & 917,7 & 774,0 \\
\hline
\end{tabular}


DETERMINATION OF COLLECTIVE EFFECTIVE AND EQUIVALENT DOSES AND RADIATION RISK OF THE UKRAINIAN POPULATION FROM $X$-RAY DIAGNOSTIC EXAMINATIONS

Stadnyk L.L., Nosyk O.V.

SI «S.P. Hryhoriev Institute for Medical Radiology, National Academy of Medical Sciences of Ukraine», Kharkiv, Ukraine

Objective: We determined the collective effective and equivalent doses of the Ukrainian population and evaluated the radiation risks by the selected types of $X$-ray examinations.

Materials and methods: The collective equivalent and effective doses of the population from the most widespread types of $X$-ray diagnostic examinations were calculated on the basis of the data of the national questionnaire of the research structure and the $X$-ray equipment park in Ukraine. The equivalent and effective doses of a "standard" patient at the $X$-ray exams were obtained from the results of the phantom modeling of the conditions of patient's exposure and previous studies of the patients' entrance surface doses. The absolute and relative radiation risks of the additional cancer cases in the Ukrainian population from X-ray diagnostic examinations were evaluated.

Results and discussion: It has been established that during $X$-ray diagnostic studies on the old models of $X$-ray machines (analog systems), the effective doses of «standard» patients are 1.1-5.5 times higher than on modern devices with digital image receivers. This is due to the use of higher exposure values on analog devices. In recent years, there has been a tendency to decrease the absolute values of collective doses, which is associated with a decrease in the country's population and a partial replacement of analog devices with digital imaging systems. The main contribution to the total collective effective dose of the population of Ukraine from the $X$-ray diagnostic examinations is provided by film fluorography - from $53.9 \%$ in 2011 to $40.0 \%$ - in 2017, while the contribution of digital fluorography is $2.8-6.7 \%$ in the years of observation. The absolute expected risk due to the most common and dose-forming types of X-ray diagnostic examinations in the projection radiology is 1485 cases per year, the film fluorography makes the main contribution - 697 cases, while digital fluorography - 117 cases.

Conclusion: The population's collective effective dose in Ukraine due to the most common examinations in projection $X$-ray diagnostics was 22.9 thousands man-Sv in 2017, whereas in 2011 37.5 thousands people. The absolute risk of the additional cancer cases due to the selected types of $X$-ray diagnostic examinations is 1485.6 cases per year, while the contribution of film fluorography is $47 \%$. The contribution of $X$-ray examinations to the increase in cancer incidence (attributive risk) made up $1.47 \%$. The largest contribution is made by film fluorography $-0.95 \%$ due to mass screening of lung diseases. Due to the fact that the attributive risk of film fluorography exceeds the acceptable risk, urgent measures are required to remove the film fluorography from radiological practice.

Keywords: $X$-ray studies, collective effective and equivalent doses, radiation risks. тканину, Зв; $\mathrm{r}_{\mathrm{T}}$ - коефіцієнт ризику радіаційного ефекту у вигляді виникнення онкологічного захворювання для окремого органа/тканини, Зв 1 .

У таблиці 2 представлено значення коефіцієнтів радіаційних ризиків опромінення для дорослих осіб різної статі для найбільш радіочутливих органів та тканин згідно 3 Публікацією МКРЗ № 103 [2].

Атрибутивний ризик визна- чався як частка (\%) абсолютного ризику виникнення радіаційних ефектів в органі за рахунок певного виду рентгенодіагностичного дослідження до статистичного показника виникнення злоякісного ново-

Рисунок 1

Значення колективних ефективних доз за основними видами досліджень у проекційній рентгенодіагностиці на 100 тис. населення України

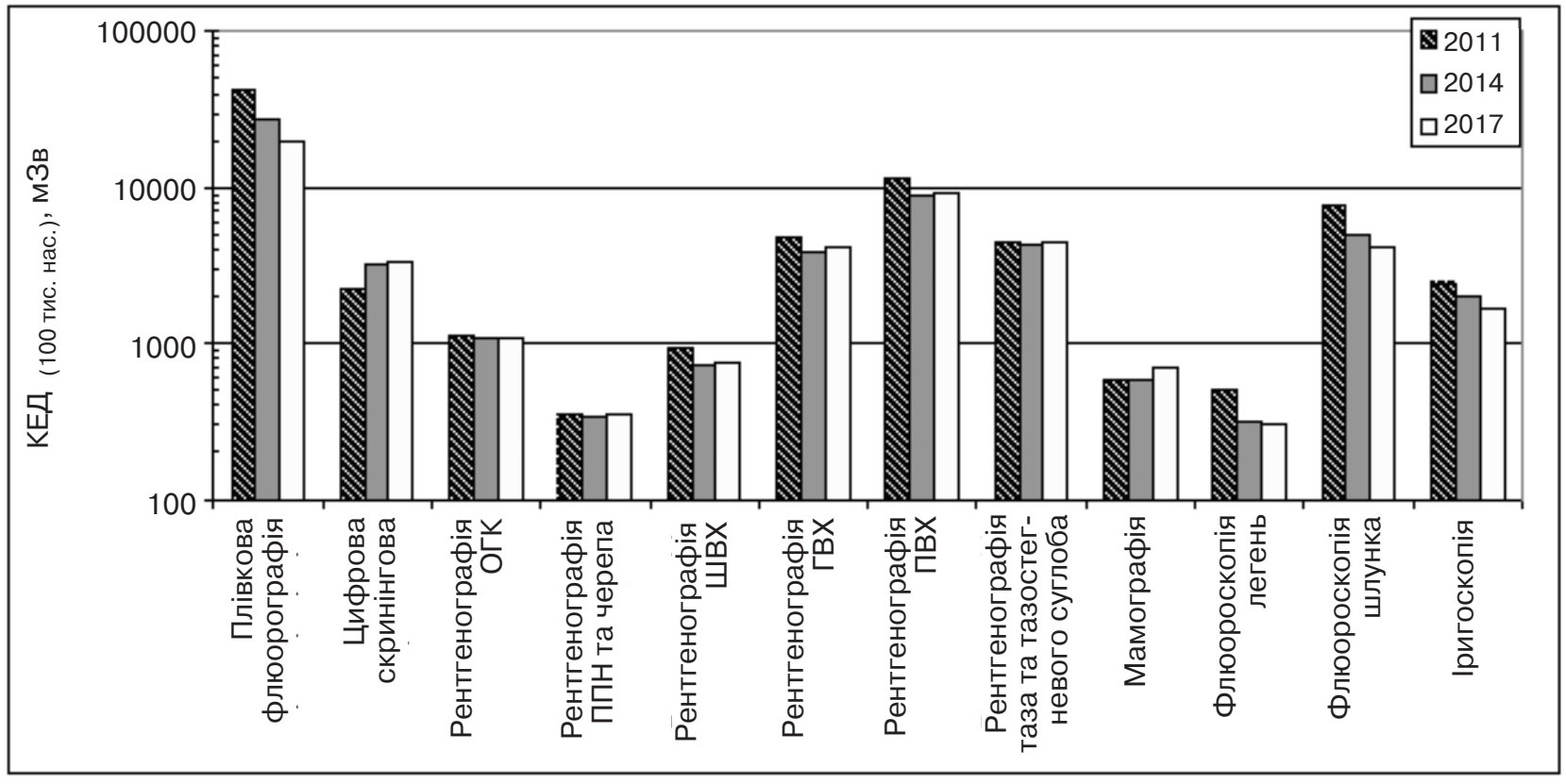

7 Thvirovinest \& IIEarmi № 42019 
утворення в окремому органі/тканині для усього населення та окремо для чоловіків і жінок за даними канцерреєстру України [8].

Окремо за кожним видом рентгенівського дослідження розраховували радіаційні ризики на 100 тисяч населення обох статей і на 100 тисяч чоловіків та 100 тисяч жінок:

$$
\frac{\mathrm{AR}_{\mathrm{T}}=E A R_{\mathrm{T}, 100 \text { тис. }}}{\mathrm{m}_{\mathrm{T}, 100 \text { тис. }}},
$$

де $\mathrm{AR}_{\mathrm{T}}$ - атрибутивний ризик онкологічного захворювання в органі за рахунок ј-го виду рентгенодіагностичного до-

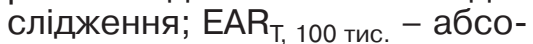
лютний ризик виникнення радіаційних ефектів в органі на 100 тис. населення за рахунок j-го виду рентгенодіагностич-

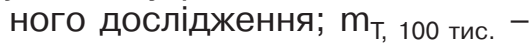
статистичний показник виник- нення злоякісного новоутворення в окремому органі/тканині на 100 тис. населення та окремо на 100 тис. чоловіків і 100 тис. жінок за даними канцер-реєстру України [8].

Результати та їх обговорення. Значення середніх ефективних доз за одне дослідження, загальна кількість проведених рентгенодіагностичних досліджень за обраними видами та колективні ефективні дози у 2011, 2014 та 2017 роках наведено у таблиці 3.

у таблиці 3 для аналогових апаратів 1 групи наведено два значення ефективної дози для флюороскопії шлунка та іригоскопії: для апаратів без підсилювача рентгенівського зображення (ПРЗ) з застарілими екранами-люмінофорами та 3 ПР3.

Як видно із таблиці 3, для рентгенографічних досліджень та флюорографії на апа- ратах 1 групи ефективні дози були в 1,1-5,5 разів вищими, ніж на апаратах 2 групи. Це пов'язане 3 використанням високих значень експозиції на апаратах 1 групи.

Для флюороскопії ОГК середні значення ефективних доз на аналогових апаратах становили 0,47 мЗв, тоді як на цифрових - 0,38 мЗв. Для флюороскопії ШКТ середні значення ДДП коливалися від 2,4 мЗв для апаратів з цифровим приймачем зображення до 30,2 мЗв для апаратів старих моделей, які не оснащені підсилювачем зображення. Для іригоскопії середні значення ДДП становили від 4,5 м3в до 20,4 мЗв для нових апаратів з цифровим приймачем зображення та аналогових апаратів ПРЗ відповідно.

Ефективна доза для мамографії складала сумарну дозу за чотирма знімками - по 2

\section{Розподіл колективних ефективних доз за основними видами рентгенодіагностичних досліджень у 2011, 2014 та 2017 роках}

Рисунок 2

2011

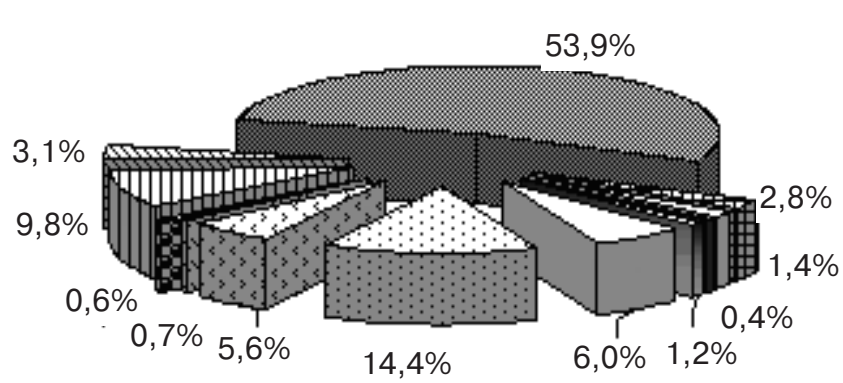

2017

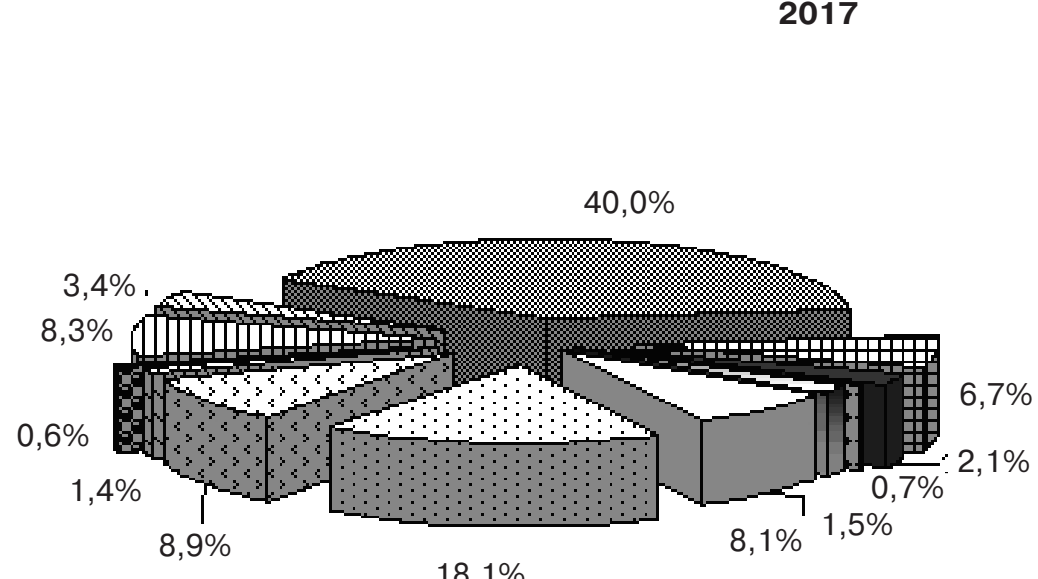

2014

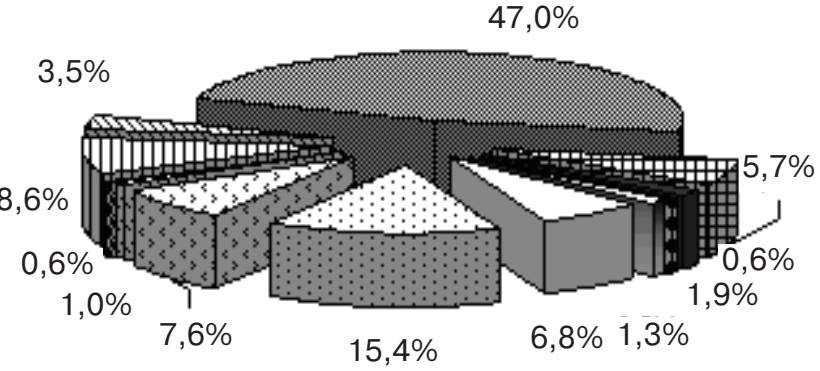

읐 Плівкова флюорографія

ВЦифрова скринінгова

口 Рентгенографія ОГК

घ Рентгенографія ППН та черепа

口Рентгенографія ШВХ

口Рентгенографія ГВХ

๑ Рентгенографія ПВХ

$\square$ Рентгенографія таза та тазостегневого суглоба

๑ Мамографія

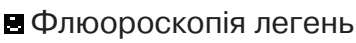

口Флюороскопія шлунка

⿶ Іригоскопія 
знімки на кожну залозу у двох проекціях (краніо-каудальній та медіо-латеральній). Встановлено, що середнє значення ефективної дози становить 0,66 мЗв - для плівкових апаратів та 0,36 мЗв для цифрових.

Найбільш масовим видом дослідження $є$ плівкова флюорографія. Однак за останні роки кількість таких досліджень суттєво зменшилася від 17,8 млн. досліджень (2011 р.) до 8,3 млн. (2017 р.) у зв'язку зі збільшенням кількості апаратів для проведення цифрової скринінгової рентгенографії легенів.

у 2011-2017 роках кількість рентгенографічних досліджень майже не змінилася, тоді як кількість флюороскопічних досліджень зменшилася в 1,31,8 рази. Це пов'язане з поширенням новітніх методів візуалізації, таких як цифрова гастроскопія, цифрова колоноскопія, комп'ютерна томографія тощо.

За останні роки спостерігається тенденція до зменшення абсолютних значень колективних ефективних доз, що пов'язано зі зменшенням кількості населення країни та частковою заміною аналогових апаратів на цифрові системи візуалізації, для яких ефек- тивні дози пацієнтів нижчі. Згідно 3 даними служби Державної статистики України кількість населення України 2011 року становила 45,9 млн. осіб, 2014 р. - 45,4 млн., а 2017 р. - 42,6 млн.

На рисунку 1 наведено значення колективних ефективних доз (мЗв) на 100 тис. осіб для найбільш масових видів рентгенодіагностичних досліджень за даними анкетування щодо кількості проведених досліджень у 2011, 2014, 2017 роках.

Як видно з рисунка 1, за останню декаду спостерігається суттєве зменшення КЕД для плівкової скринінгової флюорографії - від 42800 мЗв до 19900 мЗв на 100 тис. населення (тобто до 2,2 рази). Це пов'язане з частковою заміною аналогових флюорографів на апарати з цифровими скринінговими системами. Колективна ефективна доза від цифрової флюорографії відповідно зросла в 1,3 рази від 2200 мЗв до 3300 мЗв на 100 тис. населення.

Колективні ефективні дози від окремих видів рентгенографічних досліджень (на 100 тис. населення) практично залишилися без змін або зменшилися до 1,3 рази за рахунок часткової заміни плів- кових апаратів на сучасні цифрові комплекси.

Для різних видів флюороскопічних досліджень КЕД зменшилися в 1,4-1,8 рази. Так, для флюороскопії легенів КЕД (на 100 тис. населення) зменшилася від 500 мЗв до 300 мЗв за рахунок зменшення кількості даних видів досліджень.

Колективні ефективні дози від мамографічних досліджень збільшилися за 2011-2017 роки в 1,2 рази за рахунок збільшення кількості таких досліджень згідно 3 програмою мамографічного скринінгу жінок у країні.

На рисунку 2 наведено розподіл колективних ефективних доз за основними видами рентгенодіагностичних досліджень за 2011, 2014 та 2017 роки.

Як видно з рисунка 2, основний внесок у сумарну колек-

Таблиця 4

Колективні еквівалентні дози органів за рахунок обраних видів рентгенодіагностичних досліджень

\begin{tabular}{|c|c|c|c|c|c|c|c|c|c|}
\hline \multirow{3}{*}{ Орган, тканина } & \multicolumn{9}{|c|}{ Колективні еквівалентні дози, люд.-Зв } \\
\hline & \multirow{2}{*}{$\begin{array}{c}\text { Плівкова } \\
\text { флюоро- } \\
\text { графія }\end{array}$} & \multirow{2}{*}{\begin{tabular}{|c|} 
Цифрова \\
флюоро- \\
графія
\end{tabular}} & \multicolumn{6}{|c|}{ Рентгенографія } & \multirow{2}{*}{$\begin{array}{l}\text { Мамо- } \\
\text { графія }\end{array}$} \\
\hline & & & ОГК & $\begin{array}{l}\text { ППН, } \\
\text { череп }\end{array}$ & ШBX & ГВХ & ПВХ & Таз & \\
\hline Щитоподібна залоза & 5762,0 & 967,0 & 479,0 & 522,0 & 3246,0 & 601,0 & 84,9 & 0,5 & 0,0 \\
\hline Молочна залоза & 7271,0 & 1220,0 & 357,0 & 0,0 & 0,0 & 11723,0 & 188,0 & 0,0 & 6497,0 \\
\hline Стравохід & 14268,0 & 2394,0 & 599,0 & 217,6 & 590,0 & 1439,0 & 293,4 & 0,2 & 0,0 \\
\hline Легені & 31441,0 & 5276,0 & 1585,0 & 325,0 & 337,0 & 2178,0 & 500,0 & 0,4 & 0,0 \\
\hline Печінка & 9055,0 & 1519,0 & 364,0 & 0,0 & 0,0 & 3683,0 & 5802,0 & 378,3 & 0,0 \\
\hline Товстий кишечник & 386,0 & 64,8 & 117,2 & 0,0 & 0,0 & 3,4 & 7764,0 & 2203,0 & 0,0 \\
\hline Шлунок & 6116,0 & 1026,0 & 234,5 & 0,0 & 0,0 & 5172,0 & 16691,0 & 1323,0 & 0,0 \\
\hline Сечовий міхур & 519,0 & 87,0 & 98,1 & 0,0 & 0,0 & 0,4 & 3794,0 & 2739,0 & 0,0 \\
\hline Гонади & 194,5 & 32,6 & 107,1 & 0,0 & 0,0 & 0,0 & 1333,0 & 6725,0 & 0,0 \\
\hline Шкіра & 4733,0 & 794,0 & 431,0 & 552,0 & 282,2 & 859,0 & 3781,0 & 786,0 & 0,0 \\
\hline ЧКM & 12576,0 & 2110,0 & 700,0 & 583,0 & 578,0 & 632,0 & 2180,0 & 888,0 & 0,0 \\
\hline Поверхня кістки & 12828,0 & 2153,0 & 721,0 & 743,0 & 822,0 & 1474,0 & 1068,0 & 451,0 & 0,0 \\
\hline Інші органи & 20854,0 & 3500,0 & 926,6 & 4,3 & 566,7 & 157,4 & 1444,6 & 68,8 & 0,0 \\
\hline
\end{tabular}


тивну ефективну дозу населення України від рентгенодіагностичних досліджень дає плівкова флюорографія - від $53,9 \%$ у 2011 р. до 40,0\% - у 2017 р., тоді як вклад цифрової флюорографії становить 2,8-6,7\% за роки спостереження.

З рентгенографічних досліджень найбільший внесок у колективну дозу населення дає рентгенографія основних відділів хребта: від 26,4\% (2011 р.) до 36,6\% (2017 р.), при цьому внесок рентгенівських досліджень поперекового відділу хребта становив 14,4$18,1 \%$.

Незважаючи на суттєве зменшення кількості флюороскопічних досліджень розподіл даного типу досліджень у структурі колективної ефективної дози населення України майже не змінився: флюороскопія шлунка формує 8,39,8\% загальної КЕД населення України від проекційної рентгенології, іригоскопія - 3,1$3,5 \%$.

У таблиці 4 наведено розрахункові значення колективних еквівалентних доз на окремі найбільш чутливі органи та тканини від обра- них видів рентгенодіагностичних досліджень, проведених 2017 року.

Як видно з таблиці 4, найбільші колективні еквівалентні дози формуються у 3-5 радіочутливих органах та тканинах відповідно до виду дослідження.

Так, для флюорографії та рентгенографії ОГК - це стравохід, легені, ЧКМ, поверхня кістки. Саме на ці органи припадає найбільший ризик виникнення додаткових випадків онкологічних захворювань.

У Публікації МКР3 № 103 було вказано, що оцінка радіаційних ризиків за ефективними дозами призводить до недооцінки ризиків виникнення стохастичних ефектів в опромінених осіб [2], яку необхідно проводити за даними про колективні еквівалентні дози радіочутливих органів і тканин. Тому у роботі радіаційні ризики виникнення стохастичних ефектів у населення України за рахунок медичного рентгенодіагностичного опромінення було визначено за результатами аналізу розподілу колективних еквівалентних доз радіочутливих органів і тканин. у таблиці 5 наведено абсолютні значення радіаційних ризиків для найбільш радіочутливих органів та тканин за обраними видами рентгенівських досліджень.

За результатами розрахунків встановлено, що абсолютний очікуваний ризик виникнення додаткових онкологічних захворювань за рахунок проведення обраних видів рентгенодіагностичних досліджень у проекційній рентгенології (найбільш поширених та дозоформувальних) становить 1485,6 випадків на рік, при цьому основний внесок формує плівкова флюорографія - 697,3 випадків (47\% від загальної кількості). Внесок інших видів рентгенографічних досліджень (без урахування досліджень кінцівок та зубів) становить 374 випадки, при цьому найбільший ризик формують дослідження поперекового відділу хребта - 168,8 випадків. Радіаційний ризик флюороскопічних досліджень становить 246 випадків на рік. Загалом найбільші радіаційні ризики припадають передусім на такі радіочутливі органи, як легені, шлунок та молочна залоза.

Таблиця 5

Очікувані радіаційні ризики за рахунок проведення рентгенографічних досліджень для найбільш радіочутливих органів та тканин

\begin{tabular}{|c|c|c|c|c|c|c|c|c|c|c|}
\hline \multirow{3}{*}{ Орган, тканина } & \multicolumn{10}{|c|}{ Абсолютні ризики, кількість випадків } \\
\hline & \multirow{2}{*}{$\begin{array}{c}\text { Плівкова } \\
\text { флюоро- } \\
\text { графія }\end{array}$} & \multirow{2}{*}{$\begin{array}{c}\text { Цифрова } \\
\text { флюоро- } \\
\text { графія }\end{array}$} & \multicolumn{6}{|c|}{ Рентгенографія } & \multirow{2}{*}{$\begin{array}{l}\text { Мамо- } \\
\text { графія }\end{array}$} & \multirow{2}{*}{$\begin{array}{c}\text { Флюоро- } \\
\text { скопія }\end{array}$} \\
\hline & & & ОГК & $\begin{array}{l}\text { ППН, } \\
\text { череп }\end{array}$ & ШBX & ГВХ & ПВХ & Таз & & \\
\hline Щитоподібна залоза & 2,6 & 0,4 & 0,2 & 0,2 & 1,5 & 0,3 & 0,0 & 0,0 & 0,0 & $-{ }^{\star}$ \\
\hline Молочна залоза & 30,1 & 5,0 & 1,4 & 0,0 & 0,0 & 48,5 & 0,7 & 0,0 & 49,8 & - \\
\hline Стравохід & 19,5 & 3,3 & 0,8 & 0,3 & 0,8 & 1,9 & 0,4 & 0,0 & 0,0 & - \\
\hline Легені & 396,0 & 66,6 & 19,9 & 4,0 & 4,2 & 27,5 & 6,3 & 0,0 & 0,0 & - \\
\hline Печінка & 19,1 & 3,2 & 0,7 & 0,0 & 0,0 & 7,7 & 12,2 & 0,8 & 0,0 & - \\
\hline Товстий кишечник & 1,7 & 0,3 & 0,5 & 0,0 & 0,0 & 0,1 & 33,7 & 9,5 & 0,0 & - \\
\hline Шлунок & 32,6 & 5,5 & 1,2 & 0,0 & 0,0 & 27,5 & 88,8 & 7,0 & 0,0 & - \\
\hline Сечовий міхур & 0,9 & 0,2 & 0,1 & 0,0 & 0,0 & 0,0 & 6,8 & 4,9 & 0,0 & - \\
\hline Гонади & 0,3 & 0,1 & 0,1 & 0,0 & 0,0 & 0,0 & 2,0 & 10,3 & 0,0 & - \\
\hline Шкіра & 1,3 & 0,2 & 0,1 & 0,1 & 0,1 & 0,2 & 1,0 & 0,2 & 0,0 & - \\
\hline ЧКM & 30,1 & 5,1 & 1,6 & 1,4 & 1,4 & 1,5 & 5,2 & 2,1 & 0,0 & - \\
\hline Поверхня кістки & 4,3 & 0,7 & 0,2 & 0,2 & 0,3 & 0,5 & 0,3 & 0,1 & 0,0 & - \\
\hline Інші органи & 158,2 & 26,5 & 7,0 & 0,1 & 4,3 & 1,2 & 10,9 & 0,5 & 0,0 & - \\
\hline Абсолютний ризик & 697,3 & 117,0 & 34,4 & 6,5 & 12,6 & 117,0 & 168,8 & 35,7 & 49,8 & 246,5 \\
\hline
\end{tabular}

Примітка: * - для флюороскопічних досліджень оцінку розподілу еквівалентних доз не проводили. 
у таблиці 6 наведено абсолютні значення радіаційних ризиків проведення рентгенографічних досліджень на 100 тисяч населення України.

Як видно з таблиці 6, очікуваний радіаційний ризик від усіх видів досліджень проекційної рентгенології на 100 тисяч осіб дорослого населення України обох статей становить 3,52 випадків, з них плівкова флюорографія спричиняє 1,65 випадки, цифрова скринінгова флюорографія - 0,28, загальна рентгенографія - 0,89.

Аналіз розподілу очікуваних радіаційних ризиків виникнення онкологічних захворювань у пацієнтів за статтю (на 100 тис.) показав: у групах чоловіків ризик виникнення онкозахворювань становить 2,65 випадки. Найбільші радіаційні ризики припадають на легені, шлунок, печінку та ЧКМ. У групі жінок загальний ризик виникнення онкозахворювань майже в 1,6 рази вищий, ніж у чоловіків і становить 4,25 випадки, внесок плівкової флюорографії формує 2,03 випадки, скринінгової мамографії - 0,22. Найбільші радіа- ційні ризики припадають на легені, шлунок, молочну зало3y.

У таблиці 7 наведено результати розрахунку атрибутивного радіаційного ризику виникнення онкологічних захворювань для окремих радіочутливих органів: щитоподібної і молочної залоз, легенів, стравоходу, шлунка, товстого кишечника та лейкозів, тобто внесок (\%) обраних видів рентгенодіагностичних досліджень до загальнофонового значення онкологічної захворюваності дорослого населення України згідно 3 даними Національного канцер-реєстру [8].

Як видно із таблиці 7, за результатами розрахунків загальний атрибутивний радіаційний ризик виникнення онкологічних захворювань від обраних найбільш поширених видів рентгенодіагностичних досліджень становить 1,47\%. Найбільший внесок у загальний атрибутивний ризик додає плівкова флюорографія 0,95\% за рахунок масового обов'язкового скринінгу захворювань легень у дорослого населення країни, при цьому найбільший внесок атрибутивного ризику спостерігається для захворюваності на рак легенів - 5,41\%. Внесок загальної рентгенографії у збільшення кількості онкологічних захворювань становить $0,27 \%$.

Відповідно до концепції радіаційного ризику МКРЗ та НКДАР ООН величина прийнятного ризику смертності населення від додаткового опромінення становить 10-3. 10-4, а підвищеного радіаційного ризику - 10-3, тобто не більше $0,1 \%$ надфонової смертності [2, 9].

За результатами роботи встановлено, що для більшості

Абсолютні радіаційні ризики за рахунок проведення рентгенографічних досліджень

Таблиця 6 та ризики на 100 тисяч населення України

\begin{tabular}{|c|c|c|c|c|c|c|c|c|c|c|c|}
\hline \multirow{2}{*}{ Ризик } & \multicolumn{2}{|c|}{ Флюорографія } & \multicolumn{6}{|c|}{ Рентгенографічні дослідження } & \multirow{2}{*}{$\begin{array}{l}\text { Мамо- } \\
\text { графія }\end{array}$} & \multirow{2}{*}{$\begin{array}{c}\text { Флюо- } \\
\text { роско- } \\
\text { пія }\end{array}$} & \multirow{2}{*}{ Загалом } \\
\hline & Плівк. & Цифр. & ОГК & ППН & ШBX & ГBX & ПBХ & Таз & & & \\
\hline На 100 тис. населення & 1,65 & 0,28 & 0,08 & 0,02 & 0,03 & 0,28 & 0,40 & 0,08 & 0,12 & 0,58 & 3,52 \\
\hline 100 тис. чоловіків & 1,21 & 0,20 & 0,06 & 0,01 & 0,02 & 0,13 & 0,40 & 0,09 & - & 0,53 & 2,65 \\
\hline 100 тис. жінок & 2,03 & 0,34 & 0,10 & 0,02 & 0,04 & 0,40 & 0,40 & 0,08 & 0,22 & 0,62 & 4,25 \\
\hline
\end{tabular}

Атрибутивний радіаційний ризик проведення найбільш поширених видів

Таблиця 7 рентгенодіагностичних досліджень в Україні

\begin{tabular}{|c|c|c|c|c|c|c|c|c|c|c|c|}
\hline \multirow[b]{2}{*}{ Параметр } & \multicolumn{2}{|c|}{ Флюорографія } & \multicolumn{7}{|c|}{ Рентгенографія } & \multirow{2}{*}{$\begin{array}{c}\text { Флюоро- } \\
\text { скопія }\end{array}$} & \multirow[b]{2}{*}{ Загалом } \\
\hline & Плівкова & Цифрова & ОГК & $\Pi \Pi \mathrm{H}$ & ШBX & ГВX & $\Pi B \mathrm{X}$ & Таз & $\begin{array}{l}\text { Мамо- } \\
\text { графія }\end{array}$ & & \\
\hline $\begin{array}{l}\text { Внесок рентген. } \\
\text { досліджень в онко- } \\
\text { захворюваність, \% }\end{array}$ & 0,95 & 0,05 & 0,02 & 0,00 & 0,01 & 0,09 & 0,13 & 0,02 & 0,03 & 0,17 & 1,47 \\
\hline чоловіки & 0,67 & 0,03 & 0,02 & 0,00 & 0,01 & 0,03 & 0,13 & 0,02 & 0,00 & 0,14 & 1,05 \\
\hline жінки & 1,20 & 0,06 & 0,03 & 0,00 & 0,01 & 0,13 & 0,14 & 0,02 & 0,05 & 0,20 & 1,84 \\
\hline щитоподібна залоза & 0,16 & 0,01 & 0,01 & 0,00 & 0,06 & 0,01 & 0,00 & 0,00 & 0,00 & - & 0,25 \\
\hline Молочна залоза & 0,40 & 0,02 & 0,01 & 0,00 & 0,00 & 0,36 & 0,01 & 0,00 & 0,47 & - & 1,26 \\
\hline Стравохід & 2,22 & 0,11 & 0,05 & 0,01 & 0,05 & 0,12 & 0,03 & 0,00 & 0,00 & - & 2,59 \\
\hline Легені & 5,41 & 0,28 & 0,13 & 0,02 & 0,03 & 0,21 & 0,05 & 0,00 & 0,00 & - & 6,13 \\
\hline Шлунок & 0,72 & 0,04 & 0,01 & 0,00 & 0,00 & 0,33 & 1,15 & 0,07 & 0,00 & - & 2,33 \\
\hline Товстий кишечник & 0,02 & 0,00 & 0,00 & 0,00 & 0,00 & 0,00 & 0,22 & 0,05 & 0,00 & - & 0,30 \\
\hline Лейкоз & 1,85 & 0,09 & 0,05 & 0,02 & 0,05 & 0,05 & 0,19 & 0,06 & 0,00 & - & 2,37 \\
\hline
\end{tabular}


видів рентгенодіагностичних досліджень атрибутивний ризик онкозахворювань становив менше 0,1\%. Однак для плівкової флюорографії ризик становив 0,95\% у загальній кількості онкозахворювань, а найбільший внесок ризику від даного виду дослідження отримано для раку легенів $5,41 \%$, що значно перевищує величину прийнятного ризику та потребує термінових заходів з виключення даного виду дослідження із практичної діяльності рентгенологічної служби.

\section{Висновки}

1. Колективна ефективна доза населення України за рахунок найбільш масових досліджень у проекційній рентгенодіагностиці 2017 року становила 22,9 тис. люд.Зв на відміну від 2011 р. 37,5 тис. люд.-Зв.

Основний внесок у сумарну колективну ефективну дозу населення дають плівкова флюорографія (40,0-52,4\%), рентгенографічні дослідження основних відділів хребта (до 36,6\%, з них поперекового відділу хребта - до 18\%), флюороскопія $(9,6-12,0 \%)$.

2. Абсолютний очікуваний ризик виникнення додаткових випадків онкологічних захворювань за рахунок проведення обраних найбільш поширених видів рентгенодіагностичних досліджень у проекційній рентгенології становить 1485,6 випадків на рік, при цьому основний внесок формує плівкова флюорографія 697,3 випадків, тоді як цифрова флюорографія становить 117,0 випадків.

3. Загальний атрибутивний ризик виникнення онкозахворюваності від усіх видів процедур проекційної рентгенодіагностики становить $1,47 \%$. Найбільший внесок у загальну кількість онкозахворювань додає плівкова флюорографія $(0,95 \%)$ за рахунок проведення масового скринінгу захворювань легень. Тобто атрибутивний ризик плівкової флюорографії перевищує величину прийнятного ризику, що потребує термінових заходів щодо виключення даного виду дослідження із практики рентгенологічної служби.

\section{ЛІТЕРАТУРА}

1. Иванов В.К., Меняйло А.Н., Кащеев В.В., Чекин С.Ю.,

Горский А.И., Максютов М.А., Туманов К.А. Сравнительный анализ современных моделей оценки радиационных рисков МКРЗ и НКДАР ООН. АНРИ. 2011. № 3 (66). С. 18-29.

2. ICRP Publication 103. Recommendations of the International Commission on Radiological Protection. Ann. ICRP. 2007. Vol. 37, № 2-4. 344 p.

3. Стадник Л.Л., Шальопа О.Ю., Носик О.В. Встановлення національних діагностичних рекомендованих рівнів у рентгенодіагностиці як інструмент оптимізації медичного опромінення. Довкілля та здоров'я. 2015. № 3. С. 68-72.

4. European Commission. Radiation Protection 154:

European Guidance on Estimating Population Doses from Medical X-Ray

Procedures. Luxembourg : Office for Official Publications of the European Communities, 2008. 96 p.

5. Bly R., Jahnen A., Jrvinen H., Olerud H., Vasileva J., Vogiatzi S. Collective effective dose in Europe from X-ray and nuclear medicine procedures. Radiat. Prot. Dosimetry. 2015. Vol. 165, № 1-4. P. 129-133. doi: 10.1093/rpd/ncv094.

6. Иванов В.К., Кащеев В.В., Чекин С.Ю. Оценка радиационного риска медицинского облучения в терминах эффективной и органных доз Радиация и риск. 2012. Т. 21, № 4. С. 7-23.

7. Меняйло А.Н., Чекин С.Ю., Кащеев В.В., Максютов М.А., Корело А.М., Туманов К.А. и др. Пожизненный радиационный риск в результате внешнего и внутреннего облучения: метод оценки. Радиация и риск. 2018. Т. 27, № 1.

C. 1-21.

8. Рак в Україні, 2015-2016. Захворюваність, смертність, показники діяльності онкологічної служби. Бюл. Нац. канцер-реєстру України. К., 2017. № 18.106 c. URL : http://www. ncru.inf.ua/publications/BULL_ 18/index.htm

9. UNSCEAR 2008. Sources and Effects of Ionizing Radiation. Report to the General Assembly with Scientific
Annexes. Annex A: Medical

Radiation Exposures. New York, 2000. Vol. I. 242 p.

\section{REFERENCES}

1. Ivanov V.K., Meniailo A.N., Rashcheev V.V., Chekin S.Yu., Gorskiy A.I., Maksiutov M.A., and Tumanov K.A. ANRI. 2011 ; 3 (66) : 18-29 (in Russian).

2. ICRP Publication 103

Recommendations of the International Commission on Radiological Protection. Ann. ICRP. 2007 ; 37 (2-4) : 344 p.

3. Stadnyk L.L., Shalopa O.Yu. and Nosyk O.V. Dovkillia ta zdorovia (Environment and Health). 2015 ; 3 : 68-72 (in Ukrainian).

4. European Commission. Radiation Protection 154: European Guidance on Estimating Population Doses from Medical X-Ray

Procedures. Luxembourg : Office for Official Publications of the European Communitie ; 2008 : $96 \mathrm{p}$.

5. Bly R., Jahnen A., Jrvinen H., Olerud H., Vassileva J. and Vogiatzi S. Radiat. Prot. Dosimetry. 2015 ; 165 (14) : 129-133. doi: $10.1093 / \mathrm{rpd} / \mathrm{ncv} 094$.

6. Ivanov V.K., Kashcheev V.V. and Chekin S.Yu. Radiatsiya I

Risk. 2012 ; 21 (4) : 7-23

(in Russian).

7. Meniailo A.N., Chekin S.Yu. Kashcheev V.V., Maksiutov M.A., Korelo A.M., Tumanov K.A. et al. Radiatsiya I Risk. 2018 ; 27(1) : 1-21. Doi: 10.21870/01313878-2018-27-1-8-21

(in Russian).

8. Rak v Ukraini, 2015-2016. Zakhvoriuvanist, smertnist, pokaznyky diialnosti onkolohichnoi sluzhby [Cancer in Ukraine, 2015-2016. Morbidity, Mortality, Indicators of Oncology Service Activity]. In : Biuleten Natsionalnoho kantserreiestru Ukrainy [National Cancer Register of Ukraine]. Kyiv ; 2017 ; 18 : 106 p. URL : http://www.ncru.inf.ua/publications/BULL_18/index.htm (in Ukrainian)

9. UNSCEAR 2008. Sources and Effects of lonizing Radiation. Report to the Genera Assembly with Scientific Annexes. Annex A: Medical Radiation Exposures. New York ; 2000 ; l : 242 p.

Надійшла до редакції 12.08.2019 